\title{
Significance of Morphometric Parameters in the Categorization of Breast Lesions on Cytology
}

\section{Sitolojide Meme Lezyonlarının Sınıflandırılmasında Morfometrik Parametrelerin Önemi}

\author{
Hemant YADAV, Meenu GILL, Divya SRIVASTAVA, Veena GUPTA, Sumiti GUPTA, Rajeev SEN \\ Department of Pathology, PGIMS Rohtak, HARYANA, INDIA
}

\begin{abstract}
Objective: The aim of this study was to assess the utility of the morphometric parameters in cytological aspirates in the categorization of breast lesions.

Material and Method: The study was carried out on 50 females presenting with a breast lump for fine needle aspiration cytology. Air-dried smears from the aspirate were stained with Leishman and Giemsa stains while alcohol-fixed preparations were stained with the PAP stain. They were subsequently categorized into benign, borderline and malignant categories on light microscopy. Morphometry was performed on the stained smears. The morphometric parameters studied were mean nuclear area, mean cytoplasmic area, perimeter and nuclear/cytoplasm ratio.
\end{abstract}

Results: Morphometric parameters revealed a progressive and statistically significant increase in values from benign to borderline to malignant cases. On comparing benign with borderline and malignant, all the four parameters were found to be statistically significant with a p-value of less than 0.05 while on comparing borderline with malignant, two of the parameters, i.e. mean nuclear area and mean cytoplasmic area, were statistically significant.

Conclusion: This study introduces morphometry as a highly objective tool to supplement the entirely subjective fine needle aspiration cytology in the crucial differentiation of benign from malignant lesions and especially the borderline cases in the gray zone comprising of atypical ductal hyperplasia and ductal carcinoma in situ.

Key Words: Breast, Cytology, Morphometry

\section{ÖZ}

Amaç: Çalışmanın amacı, meme lezyonlarının sınıflandırılmasında sitolojik aspiratlardaki morfometrik parametrelerin yararının değerlendirilmesidir.

Gereç ve Yöntem: Çalışma memede kitle ile nedeni ile ince iğne aspirasyonu yapılan 50 kadın üzerinde gerçekleştirildi. Havada kurutulmuş yayma preparatlar Leishman ve Giemsa ile boyanırken alkol ile tespit edilmiş yaymalar PAP boyası ile boyandı. Olgular sonradan ş̧ık mikroskobu üzerinde benign, borderline ve malign olarak kategorize edilmiştir. Morfometri boyalı preparatlar üzerinde gerçekleştirildi. Çalışılan morfometrik parametreler ortalama çekirdek alanı, ortalama sitoplazmik alan, çevre ve çekirdek/ sitoplazma oranı idi.

Bulgular: Morfometrik parametreler benign, borderline ve malign vakalarda sırasıyla giderek artan ve istatistiksel olarak anlaml bir değer artışı gösterdi. Benign ile borderline ve malign gruplar karşılaştırıldığında , tüm dört parametre istatistiksel olarak anlamlı bulunurken $(\mathrm{p}<0,05)$ borderline ve malign grup arasinda ortalama çekirdek alanı ve sitoplazmik alan olmak üzere iki parametre istatistiksel olarak anlamlı idi.

Sonuç: Bu çalışma benign lezyonların malign ve özellikle atipik duktal hiperplazi ve duktal karsinoma in situ gibi gri zon olgulardan önem taşıyan ayırıcı tanısında tamamen sübjektif ince iğne aspirasyon sitolojisini tamamlamak üzere morfometriyi objektif bir araç olarak sunmaktadir.

Anahtar Sözcükler: Meme, Sitoloji, Morfometri

\section{INTRODUCTION}

Breast lesions account are one of the largest group of conditions necessitating pathological, radiological and surgical intervention. A palpable mass is the most common symptom of underlying malignancy and must be distinguished from the normal nodularity of the breast. The most common palpable lesions are invasive carcinomas, fibroadenomas and cysts (1).

(Turk Patoloji Derg 2015, 31:188-193)

Received : 01.05.2015 Accepted : 19.08.2015
Fine needle aspiration cytology (FNAC) is the first diagnostic modality employed for the diagnosis of breast masses. However, cytology has its own disadvantages such as interobserver and intra-observer variability. This "gray zone" in cytology is estimated to constitute $8.9 \%$ of cases. This encompasses three categories - technical limitations (4.5\%), inexperience of the cytopathologist (2.4\%) and overlap of cytological features of benign vs. malignant (2\%) (2).

Correspondence: Hemant YADAV

House No 1477/21 Adarsh Nagar, Rohtak, HARYANA, PIN 124001, INDIA

E-mail: hemantyadav7022@gmail.com Phone: + 9991257022 
Alterations in nuclear structure are the morphologic hallmarks of cancer diagnosis. A large number of parameters have been studied by morphometry, but nuclear parameters such as area, perimeter, diameter or axes have consistently been found to be significant.

The progression pattern of nuclear morphometric parameters have shown gradually increasing values from benign to atypical, ductal carcinoma in situ (DCIS) and further to invasive carcinoma and carcinoma with lymph node involvement.

In this era of automation, this study introduces morphometry as a highly objective tool to supplement the entirely subjective FNAC in the crucial differentiation of benign from malignant lesions.

\section{MATERIAL and METHODS}

This prospective study was conducted on patients presenting with breast masses in the Department of Pathology after obtaining ethical clearance from P. G. Board of studies of our institute.

A total of 50 cases were included in the study. FNAC was performed with a 23-gauge needle on patients presenting with a breast lump. Air-dried smears were made by direct drying while one of the cytological smears was fixed in $95 \%$ ethanol. Air-dried smears were subsequently stained with the Leishman and Giemsa stains while alcohol-fixed preparations were stained with the Papanicolaou (PAP) stain.

Stained slides were examined on the light microscope with subsequent categorisation into benign, borderline and malignant categories (Figure 1A, 2A, 3A). All the cases were finally confirmed on histopathology.

\section{Morphometric Analysis}

The PAP-stained smears were subjected to quantitative morphometric studies by image analysis software. Images provided by a charged video camera coupled with the Olympus BX 51 microscope at a magnification of 200X were stored on host the computer based on a Pentium 4 processor with the Microsoft Windows Vista operating system through a digital frame grabber and processing was done by the image analyzer software Microsoft ImagePro Plus version 6.3. The area on the slide to be imaged was visually selected. Random cell clusters with minimum overlapping of nuclei were selected, excluding any damaged cell cluster. Measurements were made with 20X objective magnification which when added to the $10 \mathrm{X}$ video ocular resulted in an image magnification of 200X on the monitor screen.

\section{Nuclear Features}

The cells with a clearly identifiable nuclear border were selected in each microscopic field (Figure 1B, 2B,3B). A total of a hundred nuclei were measured in each case. Nuclear features were measured by outlining their digitalized images on the monitor screen with the help of a computer mouse. Mean nuclear area and perimeter were measured by outlining the nuclear borders and clicking 'Measure'.

\section{Cytoplasmic Area}

Cytoplasmic area in the cells with clearly visible cell boundaries was measured by outlining the cell borders. If this was not possible, the cytoplasm of adjacent cells with the nuclei in focus was divided between the cells.
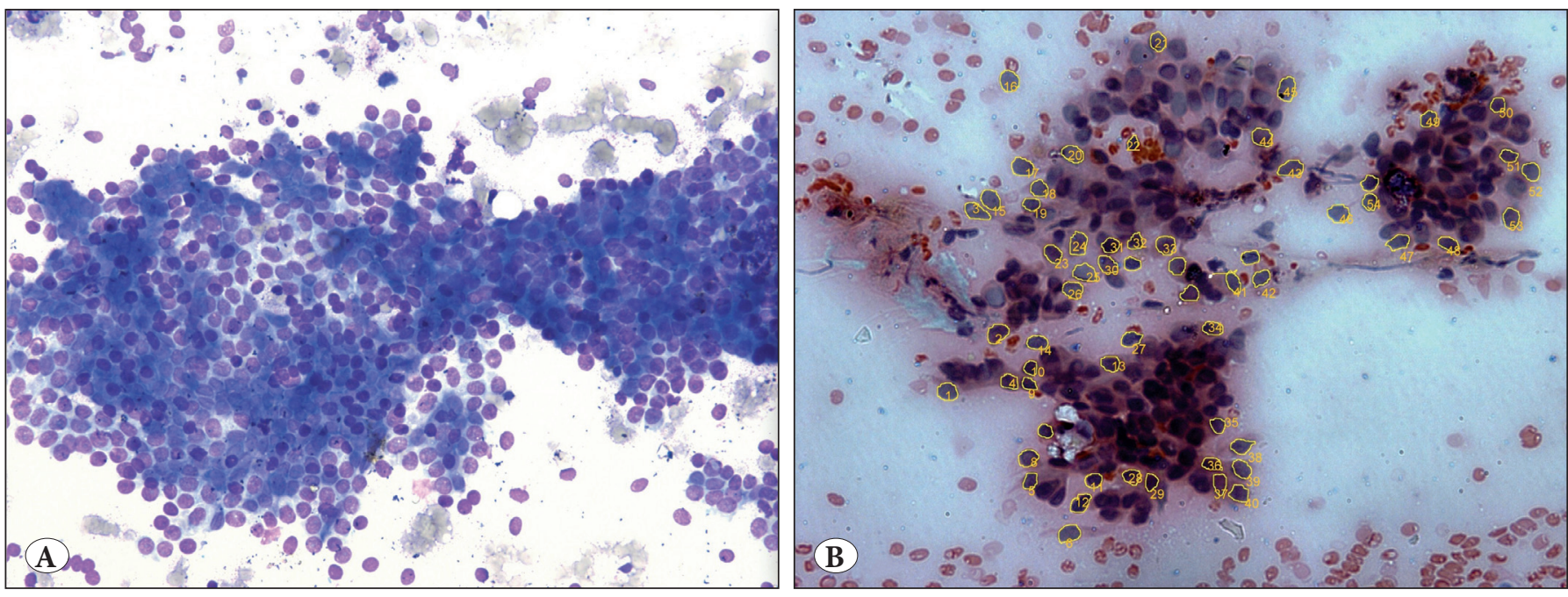

Figure 1: A) Benign breast lesion; (Leishman; x200), B) Morphometric study (PAP; x200). 

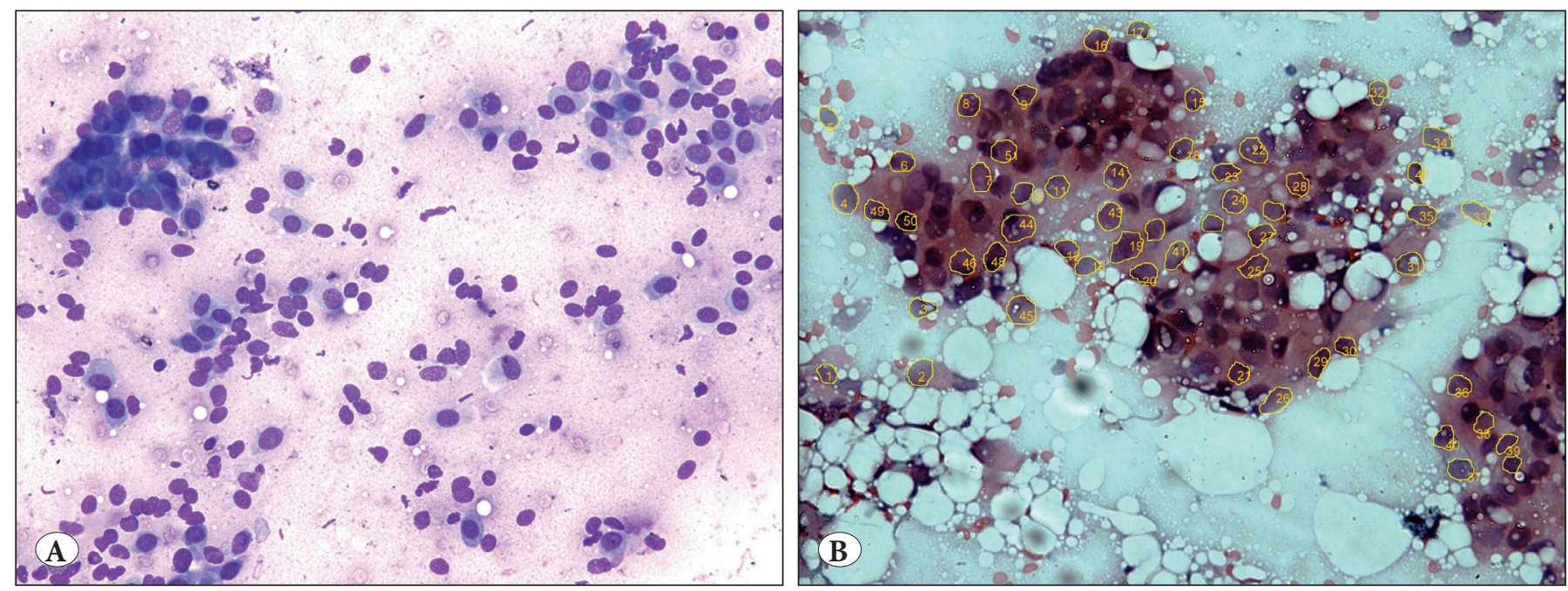

Figure 2 : A) Cellular smear from borderline lesion revealing atypical cells with enlarged pleomorphic and hyperchromatic nuclei along with benign bimodal population (Leishman; x200); B) Morphometric study (PAP; x200).
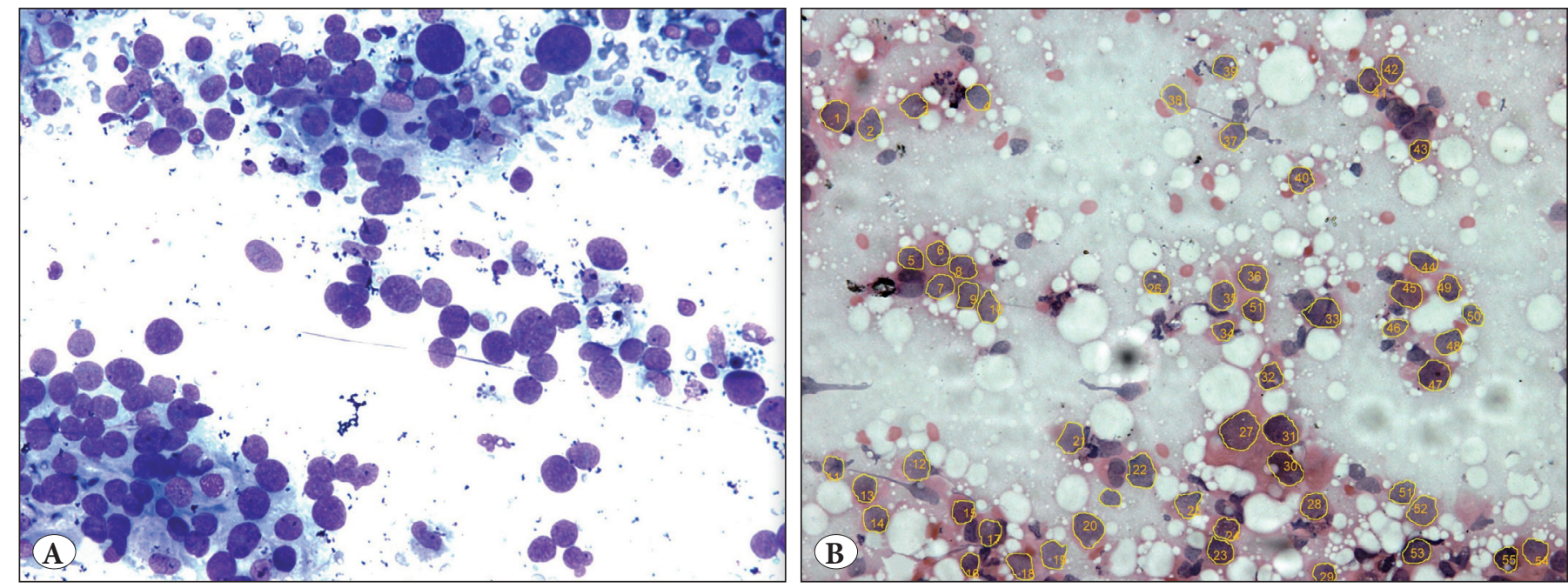

Figure 3: A) Malignant breast lesion (Leishman; x200), B) Morphometric study (PAP; x200).

\section{Nuclear to Cytoplasmic Ratio}

The nuclear to cytoplasmic ratio (N/C) was calculated by using an Excel chart.

Morphometric parameters calculated by the software were compared among different categories using the ANOVA statistical test. The post hoc statistical test was used for comparison between two categories or grades. All the statistical tests were applied via SPSS software.

\section{RESULTS}

On the basis of FNAC smears, the cases were divided into benign (11 cases), borderline (9) and malignant (30) based on their cytological appearance.
Out of the 11 benign cases reported on cytology, 8 were diagnosed as fibroadenoma and the remaining 3 as benign mammary lesion with cystic change. Nine cases with a diagnosis of proliferative mammary lesion with atypia were grouped under the borderline category. Thirty cases with a cytological diagnosis of breast carcinoma were placed under the malignant category.

Most of the benign lesions in our study were seen in the age group of 21-30 years. Borderline lesions were most commonly seen in the 30-40 years age group whereas malignant lesions had their maximum incidence in $6^{\text {th }}$ decade of life. 
As shown in Table I, a comparative analysis of morphometric parameters in various breast lesions revealed a progressive increase in the MNA, MCA, N/C ratio \& perimeter from the benign to carcinoma spectrum. These results were found to be statistically significant in all parameters $(\mathrm{p}<0.05)$.

Table II shows comparison of the morphometric parameters between the study groups. On comparing benign with borderline and malignant all the four parameters were found to be statistically significant with a p-value of less than 0.05 while on comparing borderline with malignant, two of the parameters, i.e. MNA and MCA, were statistically significant with a p-value of 0.024 and 0.043 , respectively.

Finally on cyto-histopathological correlation, all the benign and malignant cases were confirmed the same on histopathology as that of cytological diagnosis but discordance $(33.33 \%)$ was seen in borderline lesions. Out of nine cases diagnosed as borderline on cytology, five were reported as atypical ductal hyperplasia, one as DCIS and the other three as fibroadenoma.

\section{DISCUSSION}

A mass in the breast, whether benign or malignant, is a cause of anxiety for the patient and her family members. Though histopathological diagnosis is a universally accepted confirmatory mode of diagnosis and follow up, fine needle aspiration cytology of breast lumps is an important part of triple assessment (clinical examination, imaging, and FNAC) of palpable breast lumps (3). FNAC is the minimally invasive and first diagnostic modality employed for the diagnosis of breast masses. It is a useful, simple, quick, highly reproducible, and cost-effective method for the early diagnosis of breast disorders (4). In recent years, FNAC cytology is increasingly being used for the pre-operative diagnosis of breast cancer.

Alterations in cyto-nuclear features are the morphologic hallmarks of cancer diagnosis (5). The cyto-nuclear changes can be quantified by a more reproducible computer-based method known as morphometry.

The present study was planned to assess the significance of nuclear morphometry in differentiating benign and malignant breast lesions, especially in those cases where diagnostic dilemmas are encountered.

As we proceed from benign to borderline to malignant cases, there is progressive increase in MNA, perimeter, MCA and N/C ratio. The same results were reported by Narasimha et al. (6) Abdalla et al. (7) and Kalhan et al. (8) evaluated MNA in benign and malignant cases and found a more than 2 -fold increase in the values.

MNA is the most studied parameter in nuclear morphometry in the published literature $(7,9,10-13)$. In our study, an MNA of $45.45 \pm 3.88 \mu \mathrm{m}^{2}$ was observed in benign cases

Table I: Comparison of perimeter in different categories

\begin{tabular}{|c|c|c|c|c|c|}
\hline & & Benign & Borderline & Malignant & $\begin{array}{l}\text { ANOVA } \\
\text { p-value }\end{array}$ \\
\hline \multirow{2}{*}{$\begin{array}{l}\text { Nuclear } \\
\text { Area }\end{array}$} & Range $\left(\mu \mathrm{m}^{2}\right)$ & $41.00-52.30$ & $100.80-118.00$ & $90.20-128.20$ & \multirow{2}{*}{0.000} \\
\hline & Mean \pm SD $\left(\mu m^{2}\right)$ & $45.45 \pm 3.88$ & $107.03 \pm 6.60$ & $115.10 \pm 9.01$ & \\
\hline \multirow{2}{*}{$\begin{array}{l}\text { Cytoplasmic } \\
\text { Area }\end{array}$} & Range $\left(\mu \mathrm{m}^{2}\right)$ & $65.00-76.00$ & $120.00-145.10$ & $110.00-148.30$ & 0.000 \\
\hline & Mean \pm SD $\left(\mu m^{2}\right)$ & $71.54 \pm 3.21$ & $130.10 \pm 9.18$ & $137.94 \pm 9.20$ & \\
\hline \multirow{2}{*}{ N/C Ratio } & Range & $0.58-0.70$ & $0.76-0.87$ & 0.76-0.91 & 0.000 \\
\hline & Mean \pm SD & $0.63 \pm 0.05$ & $0.82 \pm 0.03$ & $0.83 \pm 0.04$ & \\
\hline \multirow{2}{*}{ Perimeter } & Range $(\mu \mathrm{m})$ & $21.50-25.00$ & $31.30-39.90$ & $30.35-41.40$ & 0.000 \\
\hline & Mean \pm SD $(\mu \mathrm{m})$ & $22.72 \pm 1.30$ & $35.01 \pm 2.73$ & $37.29 \pm 3.57$ & \\
\hline
\end{tabular}

Table II: Statistical significance of morphometric values between study groups (post hoc test)

\begin{tabular}{|l|c|c|c|c|}
\hline & MNA & MCA & N/C & Perimeter \\
\hline Benign / borderline & .000 & $\mathrm{p}=.000$ & $\mathrm{p}=.000$ & $\mathrm{p}=.000$ \\
\hline Borderline / malignant & .024 & .043 & 0.754 & .137 \\
\hline Benign / malignant & .000 & .000 & .000 & .000 \\
\hline
\end{tabular}

MNA: Mean nuclear area, MCA: Mean cytoplasmic area, N/C: Nuclear/ cytoplasmic ratio. 
Table III: Comparison of morphometric variables in different groups

\begin{tabular}{|c|c|c|c|c|c|}
\hline & & Abdalla et al $^{7}$ & Narasimha et $\mathrm{al}^{6}$ & ${\text { Kalhan et } \text { al }^{8}}$ & Present study \\
\hline \multirow{4}{*}{ Benign } & $\operatorname{MNA}\left(\mu \mathrm{m}^{2}\right)$ & $43 \pm 9$ & $71.6 \pm 9.29$ & $28.46 \pm 7.72$ & $45.45 \pm 3.88$ \\
\hline & $\mathrm{MCA}\left(\mu \mathrm{m}^{2}\right)$ & & & & $71.54 \pm 3.21$ \\
\hline & $\mathrm{N} / \mathrm{C}$ & & & & $0.63 \pm 0.05$ \\
\hline & Perimeter $(\mu \mathrm{m})$ & & $29.95 \pm 1.91$ & $19.77 \pm 2.42$ & $22.72 \pm 1.30$ \\
\hline \multirow{4}{*}{ Borderline } & $\operatorname{MNA}\left(\mu \mathrm{m}^{2}\right)$ & & $96 \pm 39.5$ & & $107.03 \pm 6.60$ \\
\hline & $\operatorname{MCA}\left(\mu \mathrm{m}^{2}\right)$ & & & & $130.10 \pm 9.18$ \\
\hline & $\mathrm{N} / \mathrm{C}$ & & & & $0.82 \pm 0.03$ \\
\hline & Perimeter $(\mu \mathrm{m})$ & & $34.27 \pm 7.26$ & & $35.01 \pm 2.73$ \\
\hline \multirow{4}{*}{ Malignant } & $\operatorname{MNA}\left(\mu \mathrm{m}^{2}\right)$ & $105 \pm 22$ & $117.33 \pm 45.50$ & $94.19 \pm 19.49$ & $115.10 \pm 9.01$ \\
\hline & $\operatorname{MCA}\left(\mu \mathrm{m}^{2}\right)$ & & & & $137.94 \pm 9.20$ \\
\hline & $\mathrm{N} / \mathrm{C}$ & & & & $0.83 \pm 0.04$ \\
\hline & Perimeter $(\mu \mathrm{m})$ & & $40.87 \pm 3.80$ & $36.19 \pm 4.91$ & $32.29 \pm 3.57$ \\
\hline
\end{tabular}

MNA: Mean nuclear area, MCA: Mean cytoplasmic area, N/C: Nuclear/ cytoplasmic ratio.

Table IV: Comparison of statistical significance of morphometric parameters between different groups

\begin{tabular}{|l|c|c|c|c|c|}
\hline & & MNA & MCA & N/C & Perimeter \\
\hline \multirow{3}{*}{ Abdalla et al $^{7}$} & Benign/borderline & - & - & - & - \\
\cline { 2 - 6 } & Borderline/malignant & - & - & - & - \\
\cline { 2 - 6 } & Benign/malignant & S & - & - & S \\
\hline \multirow{2}{*}{ Narasimha et al } & Benign/borderline & S & - & - & S \\
\cline { 2 - 6 } & Borderline/malignant & S & - & - & S \\
\cline { 2 - 6 } & Benign/malignant & S & - & - & S \\
\hline \multirow{3}{*}{ Present study } & Benign/borderline & S & S & S & S \\
\cline { 2 - 6 } & Borderline/malignant & S & S & NS & NS \\
\cline { 2 - 6 } & Benign/malignant & S & S & S & S \\
\hline
\end{tabular}

MNA: Mean nuclear area, MCA: Mean cytoplasmic area, N/C: Nuclear/ cytoplasmic ratio, S: Significant, NS: Not significant.

while malignant ones had an MNA of $115.10 \pm 9.01 \mu \mathrm{m}^{2}$, indicating a significant increase in MNA from the benign to malignant spectrum which is in concordance with studies done by Narasimha et al. (6), Abdalla et al. (7), and Kalhan et al. (8). An intermediate MNA value of $107.03 \pm 6.60$ was observed in borderline cases which is comparable to study by Narasimha et al. (6) (Table III).

The differences in the observed values of different morphometric parameters in various studies may be due to the application of different morphometric methods. However, a strictly standardized and uniform technique along with regular calibration of computerized morphometric analysers may augment the precision and accuracy, enhancing the reproducibility of results.

On comparing morphometric parameters among the three categories, the present study showed significant results on comparing various morphometric variables of benign with borderline and malignant cases. However, comparison of borderline with malignant category revealed a statistically significant role of mean nuclear area and mean cytoplasmic area while other parameters such as perimeter and N/C were found to be insignificant statistically. Abdalla et al.(7) compared MNA and perimeter between benign and malignant and the results were in concordance with the present study. In the study by Narasimha et al. (6), the results were also significant in respect to MNA and perimeter while comparing the three categories (Table IV).

In conclusion, computerized image analysis using detailed nuclear morphometry and other parameters acts as a highly objective tool supplementing the entirely subjective cytological interpretation in the successful discrimination of various breast lesions. 
Further studies on a large number of cases are needed to elucidate the role of morphometry in delineating other breast lesions like $\mathrm{ADH}$ and DCIS.

\section{CONFLICT OF INTEREST}

The authors declare no conflict of interests.

\section{REFERENCES}

1. Lester SC. The breast. In: Kumar V, Abbas AK, Fausto N, editors. Robbins and Cotran Pathologic Basis of Disease. 8th ed. Philadelphia: Saunders; 2010.1065-95.

2. Al-Kaisi N. The spectrum of the "gray zone" in breast cytology: A review of 186 cases of atypical and suspicious cytology. Acta Cytol. 1994;38:898-908.

3. Jan M, Mattoo JA, Salroo NA, Ahangar S. Triple assessment in the diagnosis of breast cancer in Kashmir. Indian J Surg. 2010;72: 97-103.

4. Chaiwun B, Settakorn J, Ya-In C, Wisedmongkol W, Rangdaeng $\mathrm{S}$, Thorner P. Effectiveness of fine-needle aspiration cytology of breast: Analysis of 2.375 cases from Northern Thailand. Diagn Cytopathol. 2002;26:201-5.

5. Pienta KJ, Coffey DS. Correlation of nuclear morphometry with progression of breast cancer. Cancer. 1991;68:2012-6.

6. Narasimha A, Vasavi B, Kumar H. Significance of nuclear morphometry in benign and malignant breast aspirates. Int J Appl Basic Med Res. 2013;3:22-6.
7. Abdalla F, Boder J, Buhmeida A, Hashmi H, Elzagheid A, Collan Y. Nuclear morphometry in FNABs of breast disease in Libyans. Anticancer Res. 2008;28:3985-9.

8. Kalhan S, Dubey S, Sharma S, Dudani S, Preeti, Dixit M. Significance of nuclear morphometry in cytological aspirates of breast masses. J Cytol. 2010;27:16-21.

9. Abdalla F, Boder J, Markus R, Hashmi H, Buhmeida A, Collan Y. Correlation of nuclear morphometry of breast cancer in histological sections with clinicopathological features and prognosis. Anticancer Res. 2009;29:1771-6.

10. Van Diest PJ, Mouriquand J, Schipper NW, Baak JPA. Prognostic value of nucleolar morphometric variables in cytological breast cancer specimens. J Clin Pathol. 1990;43:157-9.

11. Arora B, Renu, Kakade AC, Rekhi B. Diagnostic application of mean nuclear area (MNA) measured by computerized interactive morphometry in breast cancer. Int J Pathol. 2007;5:2.

12. Wittekind C, Schulte E. Computerized morphometric image analysis of cytologic nuclear parameters in breast cancer. Anal Quant Cytol Histol. 1987;9:480-4.

13. Bhambhani S, Kashyap V, Rao S. Morphological parameters and image cytometry of the fine needle aspirates of histopathologically confirmed breast and malignant breast and other lesions. Institute of Cytology and Preventive Oncology Annual Report. 2003-5. p. 38. 